\title{
Triangle Relationships among Ownership Structure, Dividend Policy and Firm Performance: An Empirical Study in Vietnamese Companies
}

\author{
Hue T. M. Nguyen ${ }^{1} \&$ Thao T. M. Giang ${ }^{1}$ \\ ${ }^{1}$ School of Banking and Finance, National Economics University, Hanoi, Vietnam \\ Correspondence: Hue T. M. Nguyen, School of Banking and Finance, National Economics University, Hanoi, \\ Vietnam. E-mail: minhhuektqd@gmail.com
}

Received: September 2, 2015

Accepted: October 24, 2015 Online Published: November 20, 2015

doi:10.5539/ass.v11n27p195

URL: http://dx.doi.org/10.5539/ass.v11n27p195

\begin{abstract}
This paper studies the triangle relationships among ownership structure, dividend policy and firm performance by investigating 34 Vietnamese companies in Construction and Construction Material industries which are listed on Hanoi Stock Exchange, Ho Chi Minh Stock Exchange, and UPCOM Stock Exchange over the period from 2011-2013. The paper studies ownership concentration, dividend payout ratio, and two measures of firm performance, namely Price to Earnings (P/E) ratio and Return on Asset (ROA). Pooled Ordinary Least Squares Model and Fixed Effect Model were used to examine three relationships between: (i) ownership concentration and dividend policy, (ii) dividend policy and firm performance, and (iii) ownership concentration and firm performance. Ownership concentration is found to increase the level of dividend payout. Dividends are positively correlated with both $\mathrm{P} / \mathrm{E}$ ratio and ROA. Finally, ownership concentration is found to have negative impacts on $\mathrm{P} / \mathrm{E}$ ratio but no significant impacts on ROA.
\end{abstract}

Keywords: dividend policy, firm performance, ownership concentration, ownership structure, P/E, ROA, Vietnam

\section{Introduction}

In the light of financial management perspective, maximizing shareholders' wealth is an appropriate objective a business firm should aim for in order to maximise the company's value. The company's value is represented by the market price of company's shares. Both managers and investors need to focus on the goal of maximizing the company's wealth, which benefits both stockholders and corporate insiders.

This goal can be achieved by optimizing three core financial decisions: investment, financing, and dividend. Among these financial decisions, not only is dividend payout policy one of the key decisions of the managers but it only creates value for and thus captures the attention of the shareholders. Dividend decision deals with the payment of dividend or distribution of profits to the shareholders in a certain period. The determinants of dividend-distributing decision and the amount of dividends are mainly based on the company's profits or surplus cash and its future growth potential. When a firm has much cash in surplus, after taking into account the need for business re-investment, it is expected to pay out a fraction or all of those surplus cash as dividends. In Vietnam, companies pay much attention in distributing values to shareholders. In a research of Bich V. and Yen D. (2014), it is found out that 68.75 to 88.64 percent of 176 listed companies paid cash dividends in the period from 2008 to 2012. The level of dividend payout was also high: the average dividend yield was 16.4 percent and dividend per share reached 5.81 percent of earning per share. The impacts of dividend policy on ownership structure and company's performance have been a central subject of various studies. However, the results still remain controversial among those studies (Kumar, 2003; Ramli, 2010; Al-Malkawi, 2007; Thomsen, 2004).

Ownership structure of firms, reflecting how equity ownership is distributed among shareholders, is a topic of major importance because it might impact managers' incentives, thereby affecting firm performance. One crucial subject in corporate governance is the impacts of large owners holding significant amount of shares. Large shareholders (block-holders) may play a valuable role in reducing the agency problems between shareholders and managers, but recent studies have paid much attention to another conflict-of-interest problem between block-holders and minority shareholders. Block-holders may prefer management authority and low dividends because they might be able to extract private benefits from controlling firms, while minority shareholders prefer high dividends. However, the results are debatable with negative, positive and insignificant relationship between 
ownership structure and firm performance (McConnel \& Servaes, 1990; Kumar, 2003; Thomsen, 2004).

In Vietnam, ownership structure can be observed with high level of ownership concentration. The ownership of Vietnamese firms, like other Asian firms such as Malaysian firms, is significantly concentrated by large institutional founders or state-owned enterprises. This fact, along with the small numbers of Vietnamese studies investigating the relationship between ownership structure and company's performance, motivates the author to carry out this paper.

However, compared to previous studies, this paper will approach a new method: besides investigating the direct relationship between ownership concentration and firm performance, an indirect approach will also be employed by examining the effects of ownership concentration on dividend policy and the effects of dividend policy on firm performance. The author hopes that the comparison of the two approaches will yield more reliable findings for the paper.

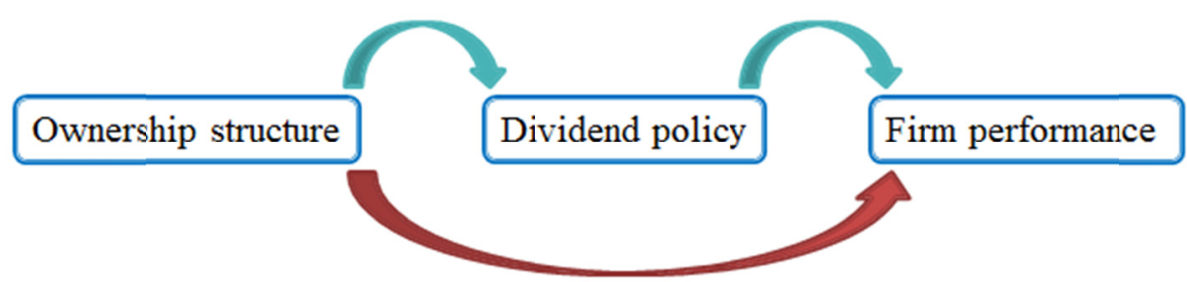

Figure 1. Research approaches

The sample data set includes 34 Vietnamese companies in Construction and Construction Material industries, which are listed on Hanoi Stock Exchange (HNX), Ho Chi Minh Stock Exchange (HOSE), and UPCOM Stock Exchange (UPCOM). These two industries are selected for analysis since they are closely related in a similar economic context. This is also because of the author's attempt to widen the data range in order to yield more reliable results. The study period is from 2011 to 2013. Ordinary Least Squares (OLS) and Fixed Effect Model (FEM) are used in five regression models as following:

Table 1. Five regression models of the paper

\begin{tabular}{ccc}
\hline Model & Dependent variable & Independent variable \\
\hline Model 1 & Dividend payout ratio & Ownership concentration \\
Model 2 & $\mathrm{P} / \mathrm{E}$ & Dividend payout ratio \\
Model 3 & $\mathrm{ROA}$ & Dividend payout ratio \\
Model 4 & $\mathrm{P} / \mathrm{E}$ & Ownership concentration \\
Model 5 & $\mathrm{ROA}$ & Ownership concentration \\
\hline
\end{tabular}

This paper is organised as follow: Section 2 presents literature review and hypothesis development. Section 3 develops the methodology including theoretical models. Section 4 presents and analyses the data results. Section 5 presents some conclusions.

\section{Literature Review and Hypothesis Development}

\subsection{The Effects of Ownership Structure on Dividend Policy}

Ramli (2010) investigated the impact of the largest shareholder on corporate dividend policy by investigating listed companies in the 2002-2006 period in Malaysia, where ownership structure is concentrated and large shareholders are in control. The study finds that the largest shareholder owns around 40 percent of the company paid-up capital. Analysis has been carried out with the view that companies' dividend policy may be used to expropriate wealth from minority shareholders. Tobit regression results suggest that companies with higher ownership concentration will pay higher dividend. Dividend payout is also larger when there is a presence of a substantial second largest shareholder in the company.

Thanatawee (2013) studied the potential link between ownership structure and dividend payout by examining 421 non-financial companies in Thailand from 2002 to 2010. The findings show that ownership concentration 
has positive impacts on both the decision to pay dividend and the amount of payment. Moreover, firms with high institutional (individual) ownership are more likely to distribute dividends and tend to distribute higher dividends. This is explained by agency theories which suggest that controlling individual shareholders expropriate minority shareholders by restricting dividend payment while major institutional shareholders could influence managers' decision to increase dividends.

In case of Jordan - an emerging market, Al-Malkawi (2005) indicated that ownership dispersion has no impact on either the decision to distribute dividends or the amount of dividend payout. Another research in Jordan of Al-Nawaiseh (2013) also studied the impact of ownership dispersion, as measured by the natural log of the number of stockholders, on the size of dividends. It is also found that there is no significant relationship between ownership dispersion and dividend policy in both Tobit analysis and Ordinary Least Squares model.

In Vietnam, however, the number of paperwork dealing with the relationship between dividend policy and ownership structure is quite modest. A study of Bich V. and Yen D. (2014) suggests that state ownership has a significance relationship with the level of dividend payout. State-owned enterprises (SOEs) tend to distribute more dividends than non-SOEs, because non-SOEs are externally funded, thus they have to retain more profits to invest in further growth.

\subsection{The Effects of Dividend Policy on Firm Performance}

According to Thomsen (2004), dividend policy has negative impacts on firm performance. The author indicates that high dividend payment today means there will be less to distribute in the future. Because firm performance is measured as the discounted cash flow to shareholders in the future, this will have a negative impact on firm performance.

The opinion of negative effects of dividend policy on firm performance is also suggested by Asquith and Mullins (1983) who pointed out that the reason is due to other costs associated with dividend payment. The companies have to pay administrative costs for dividend distribution as well as transactional costs associated with new equity issuance. The reason is that pay-out of dividends needs to be funded by new equity with given investment policy and capital structure.

On the other hand, positive relationship between dividend policy and company's performance has also been suggested by many scholars. Shareholders traditionally would prefer cash dividends. Dividend payment can help improve firm performance in the way that it is a communication method to shareholders, delivering valuable information such as increasing dividends indicating improved corporate performance and managers' commitment to maximise shareholders' value.

Nissim and Ziv (2001) suggest a positive relationship between current dividend changes and future earnings changes - one measure of profitability. The authors value profitability in terms of either future earnings or future abnormal earnings. Future abnormal earnings equal the difference between total earnings and normal earnings, and normal earnings are referred to as the shareholders' required return on the basis of the cost and level of invested equity capital. Specifically, they indicate that when using a regression model that controls for the expected changes in earnings, changes in dividend have positive impacts on changes in future earnings.

Thafani and Abdullah (2014) finds that profitability, as measured by ROA and ROE, increases with the dividend. The results suggest that firms increasing dividend payment to shareholders will experience an improvement in their profitability, whereas firms reducing the payment will face with a reduction in their profitability. Furthermore, the study emphasises that dividend payout policy is a major factor influencing the magnitude of firm profitability. Specifically, it is pointed out that increasing in dividend policy shows the improvement in firm profitability.

\subsection{The Effects of Ownership Structure on Firm Performance}

A study of Thomsen (2004) found that while in the United States and United Kingdom ownership concentration has a positive relationship with company's performance (as calculated by the ratio of equity's market value and total debt's book value over assets' book value), in Europe the relationship is negative. The negative relationship in European firms is non-linear: block-holder ownership at 60 percent or below negatively impacts firm performance, but when it rises further, it improves company's performance. The negative impacts may reflect possible expropriation of block-holders, but when ownership is concentrated in the hands of some block-holders, the positive impacts may reveal that the block-holders internalise more of the consequences of their actions.

Wahla et al. (2012) found that managerial ownership and firm performance (measured by Tobin's Q) are negatively correlated, while the relationship between ownership concentration and firm performance is insignificant. The negative impact of insider ownership is explained that high fraction of shares owned by 
corporate insiders may trigger agency problems in Pakistani, which ultimately affects firm performance.

$\mathrm{Wu}$ and Cui (2002) studied the relationship between ownership concentration and firm performance, as measured by both accounting profits and market value. It is found that ownership concentration has significant and positive impacts on firm profits, as measured by return on assets (ROA) and return on equity (ROE). However, in terms of market value as measured by price-earnings ratio $(\mathrm{P} / \mathrm{E})$ and market price to book value ratio $(\mathrm{M} / \mathrm{B})$, the relationship is significantly negative.

Neghabi and Mahmoodnia (2015) also found a negative relationship between ownership concentration and market-based performance when investigating manufacturing and trading firms in Iran. This finding is explained by agency theory that large shareholders often use their voting power to control some firm activities for their self-interests in the expense of minority shareholders and may be not really ready for transacting stocks to maintain their control.

However, Khoshkhoo et al. (2013) indicates an opposite result that there is a positive relationship between ownership concentration and market-based firm performance, as calculated by stock return and P/E ratio. As such, the authors conclude that ownership concentration improves corporate performance. It is explained that ownership dispersion leads to agency problem between shareholders and managers because the shareholders will have less control over firm managerial decisions. Therefore, high level of ownership concentration will help decrease agency costs, enabling the shareholders to supervise managers' performance.

\section{Methodology}

\subsection{Data Collection}

This study will construct a panel data from a list of 34 Vietnamese companies in Construction and Construction Material industries in the 2011-2013 period. This data set is built from 132 Vietnamese companies listed on HNX, HOSE and UPCOM, including 81 companies in Construction industry and 51 companies in Construction Material industry. Companies that did not paid cash dividends for at least two consecutive years will be dropped out to rule out the possibility that the shorter time span for some companies would influence the results. Also companies with unavailability data of ownership structure will also be eliminated from the data set. Overall, the final data set in this study includes 34 companies in a time span of three years, meaning there are approximately 102 observations.

Data of this study is extracted from firms' annual reports, financial statements and other public financial data sources such as www.vietstock.vn, www.stockbiz.vn and www.cophieu68.com.

\subsection{Model Specification and Determination of the Most Appropriate Regression Model}

There are five models to examine the potential relationships between ownership structure and dividend policy, dividend policy and firm performance, and ownership structure and firm performance. The determination of the most appropriate model to be applied, whether it is pooled Ordinary Least Squares (OLS), Fixed Effect Model (FEM) or Random Effect Model (REM), will also be discussed.

\subsubsection{Model 1 - Testing the Effects of Ownership Structure on Dividend Policy}

To investigate the impacts of managerial ownership and ownership concentration on dividend policy, this study will analyze a model with dependent variable being dividend payout ratio, and independent variables including: (i) the fractional shares owned by the first largest shareholders $\left(\mathrm{FIRST}_{\mathrm{ti}}\right.$ ) and (ii) a dummy variable (DUMSEC $\mathrm{ti}_{\mathrm{ti}}$ ) taken the value of 1 if the second largest shareholding is equal or over 5 percent, 0 if otherwise (following Ramli, 2010).

Following Al- Gharaibeh et al. (2013), in order to control for the other possible determinants of dividend policy not captured by the ownership variables, the author also includes some control variables $\left(\mathrm{CONTROL}_{\mathrm{t}}\right)$ including earnings per share $\left(\mathrm{EPS}_{\mathrm{ti}}\right)$, firm size $\left(\mathrm{SIZE}_{\mathrm{t}}\right)$, leverage ratio $\left(\mathrm{LEV}_{\mathrm{ti}}\right)$, and market to book value $\left(\mathrm{MTBV}_{\mathrm{ti}}\right)$.

Thus, the first model to be analyzed in this paper is:

$$
\log \left(D_{t i}\right)=\alpha+\beta_{1} * \log \left(\text { FIRST }_{t i}\right)+B_{2} * \text { DUMSEC }_{t i}+\beta_{3} * C_{\text {CONTROL }}+\mu_{t i}
$$

Detail of the dependent and independent variables in the model is shown in Table 2: 
Table 2. Dependent and independent variables of Model 1

\begin{tabular}{|c|c|}
\hline \multicolumn{2}{|c|}{ DEPENDENT VARIABLE } \\
\hline $\mathrm{D}_{\mathrm{ti}}$ & : Dividend per share at time $\mathrm{t}$. \\
\hline \multicolumn{2}{|c|}{ INDEPENDENT VARIABLES } \\
\hline FIRST $_{\mathrm{ti}}$ & : The proportional of shares owned by the first largest shareholders. \\
\hline$\therefore$ DUMSEC $_{\mathrm{ti}}$ & $\begin{array}{l}\text { : A dummy variable taken the value of } 1 \text { if the second largest shareholding is equal or } \\
\text { more than } 5 \text { percent, } 0 \text { if otherwise }\end{array}$ \\
\hline \multicolumn{2}{|c|}{ CONTROL VARIABLES (or CONTROL $_{\mathrm{ti}}$ in the above equation) } \\
\hline$* \mathrm{EPS}_{\mathrm{ti}}$ & : Earning per share of firm $i$ at time $t$. \\
\hline$\nLeftarrow$ SIZE $_{\mathrm{ti}}$ & : Natural log of total assets. \\
\hline$* \mathrm{LEV}_{\mathrm{ti}}$ & : Ratio of the book value of total debt to total equity. \\
\hline * $\mathrm{MTBV}_{\mathrm{ti}}$ & : Future growth opportunities measured as the ratio of market to book value of equity. \\
\hline
\end{tabular}

\section{- Control variables:}

$>\mathrm{EPS}_{\mathrm{ti}}$ is the ratio of net profits over the total number of ordinary shares outstanding. The higher the EPS, the higher the possibility that firms are generating huge cash from operation and likely to distribute the surplus cash as dividends to shareholders.

$>$ SIZE $_{\mathrm{ti}}$ : Larger firms may have more resources and financial capability in surplus to pay out cash to the shareholders. Smith and Watts (1992) state that firms owning more assets tend to pay more dividends. The firms' size in this paper is measured as the natural log of total assets: $\mathrm{SIZE}_{\mathrm{ti}}=\ln$ (Total Assets $_{\mathrm{ti}}$ ).

$>\mathrm{LEV}_{\mathrm{ti}}$ : It is predicted by the recent studies that the financial leverage has negative effects on dividend payout (Jensen 1986 and Stulz 1990). It is suggested that financial leverage can help monitor managers' behavior, thus reducing the agency problem and the need to pay out dividends.

> $\mathrm{MTBV}_{\mathrm{ti}}$ : Amidu and Abor (2006) state that with greater anticipated growth potential, a company will pay fewer dividends because it is preferable to retain a greater amount of cash for investment in growth rather than using external funds which is associated with paying transaction costs.

The hypothesis is:

Hypothesis 1: Ownership concentration has positive effects on dividend policy.

Regarding the regression model to be applied, the author use Redundant Fixed Effect - Likelihood Ratio to choose between OLS and FEM with the null hypothesis being OLS is the appropriate model. As p-value is 0.099 which is higher than the significant level of 5 percent, the null hypothesis is not rejected; thus, OLS is appropriate for Model 1.

\subsubsection{Model 2A \& 2B - Testing the Effects of Dividend Policy on Firm Performance}

Following Khoshkhoo et al. (2013), P/E ratio ( $\left.\mathrm{P}_{-} \mathrm{E}_{\mathrm{ti}}\right)$ will be chosen as dependent variable as one of the most important market based criteria for evaluating corporate performance. Also following Kumar (2003) and Thomsen (2004), another indicator for firm's accounting based performance, $\mathrm{ROA}_{\mathrm{ti}}$, will also be chosen as dependent variable in another model. Independent variable is dividend payout ratio $\left(\mathrm{D}_{\mathrm{ti}}\right)$. In order to control for the other possible determinants of firm performance not captured by the ownership variables, the author also includes some firm characteristics as control variables including size $\left(\mathrm{SIZE}_{\mathrm{t}}\right)$, leverage ratio $\left(\mathrm{LEV}_{\mathrm{ti}}\right)$, asset turnover ratio $\left(\mathrm{ASTURN}_{\mathrm{ti}}\right)$ and growth in sales $\left(\mathrm{SALESGR}_{\mathrm{ti}}\right)$. The control variables used in the study have been selected with reference to those employed in earlier studies. Thus, this study will construct the following equations:

$$
\begin{aligned}
& \text { Model 2A: } P_{-} E_{t i}=\alpha+\beta_{1} * D_{t i}+\beta_{2} * C O N T R O L_{t i}+\mu_{t i} \\
& \text { Model 2B: } R O A_{t i}=\alpha+\beta_{1} * D_{t i}+\beta_{2} * C O N T R O L_{t i}+\mu_{t i}
\end{aligned}
$$

Detail of the dependent and independent variables in the model is explained in Table 3: 
Table 3. Dependent and independent variables of Model 2A and 2B

\begin{tabular}{|c|c|}
\hline DEPENDENT V & \\
\hline$* \mathrm{P}_{-} \mathrm{E}_{\mathrm{ti}}$ & $: \mathrm{P} / \mathrm{E}$ ratio at time $\mathrm{t}$ of firm $\mathrm{i}$. \\
\hline$* \mathrm{ROA}_{\mathrm{ti}}$ & : The ratio of return on assets calculated as net income divided by total assets. \\
\hline INDEPENDENT & LES \\
\hline$* \mathrm{D}_{\mathrm{ti}}$ & : Dividend per share at time $\mathrm{t}$. \\
\hline CONTROL VAR & (or $\mathrm{CONTROL}_{\mathrm{ti}}$ in the above equation) \\
\hline $\mathrm{SIZE}_{\mathrm{ti}}$ & : Natural log of total assets. \\
\hline$* \mathrm{LEV}_{\mathrm{ti}}$ & : Ratio of the book value of total debt to total equity. \\
\hline$*$ ASTURN $_{\mathrm{ti}}$ & : Ratio of sales/assets of the firm i. \\
\hline * SALESGR ${ }_{\mathrm{ti}}$ & : Changes of sales revenue from the year $\mathrm{t}-1$ to $\mathrm{t}$. \\
\hline
\end{tabular}

\section{- Control variables:}

$>$ SIZE $_{\mathrm{ti}}$ : The effects of firm size's on firm performance suggested in the previous studies are ambiguous. Larger companies cannot operate as efficiently as smaller ones because top managers cannot control over certain operational activities (Sarkar and Sarkar 2000). On the other hand, large firms can be more efficient as they are likely to take advantage of the economies of scale.

$>\mathrm{LEV}_{\mathrm{ti}}$ : Leverage measures financial risk because a company will have to pay interest even when it does not make profit, and failure to do so will result in bankruptcy. Thus, a company with high leverage ratio may be valued low for those investors who do not prefer risky investments. On the other hand, borrowing can actually have positive impacts on profitability as it is a cheaper way than using internal sources to fund good projects.

$>$ ASTURN $_{\mathrm{ti}}$ : This ratio is expected to have positive relationship with ROA because higher turnover means that assets are used efficiently to generate high profitability.

$>$ SALESGR $_{\mathrm{ti}}$ : Higher sales revenue over the years often goes along with higher profitability if the firms can control the increase in total costs.

The hypotheses are:

Hypothesis 2: Dividend policy has positive effects on $P / E$.

Hypothesis 3: Dividend policy has positive effects on ROA.

For Model 2A, regarding the regression model to be applied, the author use Redundant Fixed Effect - Likelihood Ratio to choose between OLS and FEM. As p-value is 0.0011, FEM is chosen. To determine whether FEM and REM is more appropriate, the author will use Hausman test with the null hypothesis being REF is appropriate. As the result shows a p-value which is 0.0016 than significance level of 5 percent, the null hypothesis is rejected, meaning FEM is more appropriate. This result is consistent with Al- Gharaibeh (2013) who suggests that fixed effects estimations are more appropriate than random effects estimations after applying Hausman test.

For Model 2B, the author use Redundant Fixed Effect - Likelihood Ratio to choose the most appropriate regression model between OLS and FEM. The result shows that FEM is more suitable than OLS as null hypothesis is rejected at p-value of 0.000 . FEM is also found to be more appropriate than REM when applying Hausman test at $\mathrm{p}$-value of 0.0444 .

Therefore, both Models 2A and 2B will be set up with FEM to test the effects of dividend payout on firm performance.

3.2.3 Model 3A \& 3B - Testing the Effects of Ownership Structure on Firm Performance

Following Kumar (2003) and Thomsen (2004), this study will construct the following equations:

$$
\begin{aligned}
& \text { Model 3A: } P_{-} E_{t i}=\alpha+\beta_{1}{ }^{*} F I R S T_{t i}+\beta_{2} * D U M S E C_{t i}+\beta_{3} * C O N T R O L_{t i}+\mu_{t i} \\
& \text { Model 3B: } R O A_{t i}=\alpha+\beta_{1}{ }^{*} \text { FIRST }_{t i}+\beta_{2}{ }^{*} D U M S E C_{t i}+\beta_{3} * C O N T R O L_{t i}+\mu_{t i}
\end{aligned}
$$

Detail of the dependent and independent variables in the model is explained in Table 4: 
Table 4. Dependent and independent variables of Model 3A and 3B

\begin{tabular}{|c|c|}
\hline \multicolumn{2}{|c|}{ DEPENDENT VARIABLES } \\
\hline$* \mathrm{P}_{-} \mathrm{E}_{\mathrm{ti}}$ & $: \mathrm{P} / \mathrm{E}$ ratio at time $\mathrm{t}$ of firm $\mathrm{i}$ \\
\hline$* \mathrm{ROA}_{\mathrm{ti}}$ & : The ratio of return on assets calculated as net income divided by total assets. \\
\hline \multicolumn{2}{|c|}{ INDEPENDENT VARIABLES } \\
\hline FIRST $_{\mathrm{ti}}$ & : The proportional of shares owned by the first largest shareholders. \\
\hline * DUMSEC ${ }_{\mathrm{ti}}$ & $\begin{array}{l}\text { : A dummy variable taken the value of } 1 \text { if the second largest shareholding is equal } \\
\text { or more than 5percent, } 0 \text { if otherwise }\end{array}$ \\
\hline \multicolumn{2}{|c|}{ CONTROL VARIABLES (or CONTROL $_{t \mathrm{i}}$ in the above equation) } \\
\hline $\mathrm{SIZE}_{\mathrm{ti}}$ & : Natural log of total assets. \\
\hline * $\mathrm{LEV}_{\mathrm{ti}}$ & : Ratio of the book value of total debt to total equity. \\
\hline$*$ ASTURN $_{\mathrm{ti}}$ & : Ratio of sales/assets of the firm i. \\
\hline * SALESGR $_{\mathrm{ti}}$ & : Changes of sales revenue from the year $t-1$ to $t$. \\
\hline
\end{tabular}

The hypotheses are:

Hypothesis 4: Ownership concentration has negative effects on P/E.

Hypothesis 5: Ownership concentration has negative effects on ROA.

For Model 3A, regarding the regression model to be applied, the author use Redundant Fixed Effect - Likelihood Ratio to choose between OLS and FEM. As p-value is 0.7335 , much higher than the significant level of 5 percent, the null hypothesis is not rejected; thus, for Model 3A, OLS is the more appropriate than FEM and REM.

For Model 3B, FEM is shown to be more appropriate than OLS and REM as p-values in both Redundant Fixed Effect - Likelihood Ratio and Hausman Test are below 5 percent of significant level.

Thus, Model 3A will be constructed using OLS and Model 3B will be constructed using FEM.

\section{Data Analysis}

\subsection{Descriptive Analysis}

Table 5 shows the distribution of the sample companies' ownership structure, while Table 6 summarizes the financial characteristics of those companies.

Table 5. Ownership structure of 34 Vietnamese listed companies in Construction and Construction Material industries in the 2011-2013 period

\begin{tabular}{ccccccc}
\hline Variable & Observation & Mean & Median & Max & Min & Standard Deviation \\
\hline FIRST & 102 & 0.3983 & 0.5100 & 0.6070 & 0.1455 & 0.1569 \\
DUMSEC & 84 & 0.6950 & 1 & 0 & 0 & 0.4651 \\
\hline
\end{tabular}

Regarding ownership structure, not all companies in Vietnam declare the data of the second largest shareholders, which is shown by the lower number of observations in the table 4.4. Among the companies studied in this paper, ownership concentration is high because the first largest shareholder (FIRST) on average holds 39.83 percent of the company's total equity with a median of 51 percent. The higher median indicates that the number of companies with significant first largest shareholding overwhelm the data set. The highest and smallest fraction of equity held by the first largest shareholder equals 60.70 and 14.55 percent. Among those Vietnamese listed companies in Construction and Construction Material industries studied in this paper, the majority has the first largest shareholders being stated-owned enterprises. The remaining companies have securities and investment companies as their first largest shareholders. Thus, first largest shareholding could also be considered as state ownership to some extent. As compared to other countries, the level of level of ownership concentration in Vietnam is not higher than Malaysian companies having mean (median) of first largest shareholding being 40.21 (40.41) percent as indicated by Ramli (2010). 
About the second largest shareholding (DUMSEC), 69 percent of those companies declaring the data have the second largest shareholding above 5 percent, which is much higher than that in Malaysia. This illustrates the high level of ownership concentration among selected companies as shareholding above 5 percent is considered as large or significant.

The descriptive analysis of some financial characteristics of companies in the data set is shown in Table 6:

Table 6. Firm's characteristics of 34 Vietnamese listed companies in Construction and Construction Material industries in the 2011-2013 period

\begin{tabular}{ccccccc}
\hline Variable & Observation & Mean & Median & Max & Min & Standard Deviation \\
\hline DIV & 98 & 0.1427 & 0.1400 & 0.4300 & 0.0100 & 0.0693 \\
P/E & 102 & 6.7388 & 4.73 & 30.24 & 1.16 & 5.9017 \\
ROA & 102 & 0.0436 & 0.0332 & 0.1678 & 0.0015 & 0.0377 \\
EPS & 102 & 2486.483 & 2048 & 7890 & 163 & 1660.499 \\
SIZE & 102 & 13.3582 & 13.6143 & 15.8970 & 10.6455 & 1.2963 \\
LEV & 102 & 2.9884 & 2.6744 & 10.2838 & 0.0790 & 2.2867 \\
MTBV & 102 & 0.5803 & 0.5100 & 1.7800 & 0.1800 & 0.2859 \\
ASTURN & 102 & 0.9753 & 0.8650 & 2.8 & 0.04 & 0.5757 \\
SALESGR & 102 & 0.1199 & 0.0739 & 1.9795 & -0.5385 & 0.3656 \\
\hline
\end{tabular}

There are only 98 observations of $D I V$ because some companies decided not to pay dividends in one of the years during the period. On average dividend payout in Vietnamese companies in Construction and Construction Material companies from 2011 to 2013 equals to 14.27 percent and the median equals 14 percent (equivalent to $1,400 \mathrm{VND} /$ share). The largest dividend payout is as high as 43 percent, but the lowest dividend payout is only 1 percent, showing the significant difference in dividend payout policy among companies.

$P / E$ as an indicator of market based firm performance has a mean (median) of 6.7388 (4.73) and maximum (minimum) value of 30.24 (1.16), indicating the deviation in market performance of sample firms despite being in closely related industries. Another indicator, $R O A$, shows wider variation in accounting based performance of sample firms. ROA ranges from 0.15 to 16.78 percent with mean (median) of 4.36 (3.32) percent. The lower median indicates that there are more firms in the range of low ROA.

EPS of companies in Construction and Construction Material industries is quite high with mean (median) at 2486.483 (2048) VND/per share. The companies investigated in this study do not vary much in terms of SIZE as measured by natural log of total assets, which ranges from VND 15.8970 to 10.6455 million. Firm size has mean (median) of VND 13.3582 (13.6143) million.

However, the other ratios indicate much variation in the performance of sample firms. Leverage (LEV), as calculated by the ratio of total debt over total equity, is high with mean (median) of 298.84 (267.44) percent, which shows that companies in those industries utilise a large number of external funds for their operation. $M T B V$, as equivalent to $\mathrm{P} / \mathrm{B}$, is quite high with an average (median) of 58.03 (51.00) percent, suggesting that firms having good potential for growth. Regarding operation efficiency, sample companies has asset turnover rate (ASTURN) of 0.9753 on average, which is good for companies in Construction and Construction Material industries which are usually asset-intensive. Finally, average sales growth rate (SALESGR) of those firms is also impressive at 11.99 percent with median of 7.39 percent. However, there are some companies with exceptionally high growth potential of 197.95 percent, but at the same time some of the companies performed adversely with negative sales growth (-53.85 percent).

\subsection{Empirical Results}

\subsubsection{Model 1 - Testing the Effects of Ownership Structure on Dividend Policy}

The empirical results of Model 1 are summarised in Table 7: 
Table 7. Empirical results of Model 1

\begin{tabular}{cccc}
$\log \left(D_{t i}\right)=\alpha+\beta_{1} * \log \left(\right.$ FIRST $\left._{t i}\right)+B_{2}{ }^{*}$ DUMSEC $_{t i}+\beta_{3}{ }^{*}$ CONTROL $_{t i}+\mu_{t i}$ & \\
\hline Dependent variable & & LOG(DIV $)$ & Relationship \\
\hline Independent variables & Coefficient & P-value & Significant \\
\hline LOG(FIRST) & 0.301924 & 0.0253 & \\
DUMSEC & -0.067557 & 0.5523 & Significant \\
EPS & 0.000232 & 0.0000 & \\
SIZE & -0.082367 & 0.0798 & Significant \\
LEV & 0.007370 & 0.7944 & \\
MTBV & 0.447745 & 0.0093 & \\
R-squared & & 0.554019 & \\
Prob (F-statistic) & & 0.002405 & \\
\hline
\end{tabular}

Overall, the model is of significance because p-value is much lower than 5 percent.

There is found to be a significant and positive relationship between ownership concentration, as represented by the first largest shareholding (FIRST), and dividend policy at p-value of 0.0253. This finding supports Hypothesis 2 and is consistent with Ramli (2010). This indicates that the dividend policy may be utilised to solve agency problem between large and minority shareholders. The agency problem is very likely to arise in companies with high ownership concentration because minority shareholders have great fear that large shareholders may use their power to decrease dividend payout and retain earnings to create private benefits. This action conflicts with the interests of minority investors who may prefer high dividends as returns for their investments. Moreover, the high level of ownership concentrated in one largest shareholder may raise the concern of expropriation. High level of dividend payout can be a signal for block-holders' unwillingness to exploit company's assets. Regarding the effect of the second largest shareholder, the model does not show significant relationship between DUMSEC and dividend policy.

Among the control variables, EPS and $M T B V$ exhibit significant and positive association with dividend policy at significance level of 1 percent. This is in line with expectation of this study that higher EPS will increase dividend payout, but it is contradict with the author's expectation and findings of Amidu and Abor (2006) that higher MTBV means greater opportunity for growth and thus the companies will retain more cash for investment rather than paying out as dividends. Different from that theoretical premise, Vietnamese companies in the data set distribute high cash dividends despite having great growth potential with average sales growth rate of 11.99 percent as shown in the descriptive analysis. In this regard, it can be concluded that those companies use a part of their internal funds for dividend payout in order to distribute value to existing shareholders and attract other investors. High dividend payout can be a signal for the commitment to shareholder value creation and company's great profitability. It might be possible that those companies use both internal and external funds (i.e. borrowing, as proven by the high level of leverage) for their operation.

Finally, there is no evidence found in the model indicating significant relationships between SIZE and leverage and dividend policy.

\subsubsection{Model 2A \& 2B - Testing the Effects of Dividend Policy on Firm Performance}

Firstly, the empirical results of Model 2A are summarised in Table 8:

Table 8. Empirical results of Model 2A

$$
P_{-} E_{t i}=\alpha+\beta_{1} * D_{t i}+\beta_{2} * C_{C N T R O L}+\mu_{t i}
$$

\begin{tabular}{cccc}
\hline Dependent variable & & P/E ratio (P_E) & \\
\hline Independent variables & Coefficient & P-value & Relationship \\
\hline DIV & 41.14654 & 0.0007 & Significant \\
SIZE & -9.606668 & 0.1327 & \\
\hline
\end{tabular}




\begin{tabular}{ccc}
\hline LEV & 2.569768 & 0.1238 \\
ASTURN & 3.169272 & 0.4484 \\
SALESGR & -0.497554 & 0.7849 \\
R-squared & & 0.592523 \\
Prob (F-statistic) & & 0.000000 \\
\hline
\end{tabular}

Overall, the model is of significance because p-value is much lower than 5 percent.

Dividend payout ratio $(D I V)$ is found to help improve $\mathrm{P} / \mathrm{E}$, which supports Hypothesis 3 of the paper. This finding is opposite with some researches arguing that cash dividends will decrease firm performance because if pay-out at time $t$ is high, there will less to pay out in future periods. This may have a negative effect on firm performance, which is theoretically the discounted expected present value of future dividends. However, researchers such as Lintner (1956), Gordon (1959), Ross (1977) and Bhattacharya (1979) conclude that dividend payments can deliver valuable information to investors, thereby having positive influence on firm performance. High dividends signal that the firm is particularly successful or that its managers are particularly committed to maximizing shareholders' value. Moreover, in this paper when examining the link between dividend policy and $\mathrm{P} / \mathrm{E}$ ratio in conjunction with the effects from ownership structure, a positive relationship can be suggested. Companies in the data set have high level of ownership concentration (with an average of 39.83 percent), which may trigger agency problem between large shareholders and minority shareholders. In this case, it is suggested by Thomsen (2004) that if stock prices are set at the margin by minority investors, lower dividends and higher retained earnings could lead to lower firm performance since minority investors would correctly expect some level of self-dealing by controlling owners of firms with high retained earnings. In this regard, in companies with high ownership concentration, higher dividends may be better and help increase how much firms are valued by investors.

Results show that the effects of other control variables (SIZE, leverage, asset turnover rate and sales growth) on $\mathrm{P} / \mathrm{E}$ ratio are insignificant. This result is unexpected and may be due to the wide variation in data as a result of the inefficiency of Vietnamese market.

Secondly, the empirical results of Model 2B are summarised in the Table 9:

Table 9. Empirical results of Model 2B

\begin{tabular}{cccc}
$R O A_{t i}=\alpha+\beta_{1}{ }^{*} D_{t i}+\beta_{2}{ }^{*}$ OONTROL $_{t i}+\mu_{t i}$ & & \\
\hline Dependent variable & & ROA & \\
\hline Independent variables & Coefficient & P-value & Relationship \\
\hline DIV & 0.309262 & 0.0000 & \\
SIZE & -0.019220 & 0.2460 & \\
LEV & 0.002928 & 0.4969 & Significant \\
ASTURN & 0.029281 & 0.0088 & \\
SALESGR & -0.002639 & 0.5786 & \\
R-squared & & 0.931065 & \\
Prob (F-statistic) & & 0.000000 & \\
\hline
\end{tabular}

Overall, the model is of significance because p-value is much lower than 5 percent. Furthermore, the $\mathrm{R}$ squared of 93.106 percent reveals the high accuracy of the model in which over 93 percent of variation of ROA is captured by changes of predictor variables. Therefore, Model 2B is very reliable in explaining the relationship between dividend policy on firm performance.

Similar to Model 2A, DIV in Model 2B also shows positive and significant impacts on ROA. This result is in line with Nissim and Ziv (2001) and Thafani and Abdullah (2014). Lie (2005) argued that firms that increase payout have excess financial flexibility and exhibit positive concurrent income shocks and decreases in income volatility. He stated that firms that increase payout have lower past volatility of operating income than other 
firms. This can be explained by the fact that managers increase the firm's payout when they believe that the probability of sustaining the current level of income is high. Firms that decrease dividends on the other hand, have higher past volatility than other firms, and this volatility is on the rise.

Although no significant relationship between firm size, leverage and sales growth and firm performance is found due to the variation of data, asset turnover rate exhibits a significant positive connection with ROA.

4.2.3 Model 3A \& 3B - Testing the Effects of Ownership Structure on Firm Performance

Firstly, the empirical results of Model $3 \mathrm{~A}$ are summarised in the Table 10:

Table 10. Empirical results of Model 3A

$P_{-} E_{t i}=\alpha+\beta_{1} * F_{R S S T}+\beta_{2} * D U M S E C_{t i}+\beta_{3} * C{ } O N T R O L_{t i}+\mu_{t i}$

\begin{tabular}{cccc}
\hline Dependent variable & & P/E ratio (P_E) & \\
\hline Independent variables & Coefficient & P-value & Relationship \\
\hline FIRST & -15.93082 & 0.0019 & Significant \\
DUMSEC & 1.971742 & 0.1880 & \\
SIZE & -0.279832 & 0.6899 & \\
LEV & 0.605651 & 0.0962 & \\
ASTURN & -0.101003 & 0.9431 & \\
SALESGR & 1.037636 & 0.5514 & \\
R-squared & & 0.167927 & \\
Prob (F-statistic) & & 0.027934 & \\
\hline
\end{tabular}

Overall, the model is of significance because p-value is lower than 5 percent.

Ownership concentration, as measured by the first largest shareholding, also has a negative relationship with firm market value at p-value of 0.0019, which is in line with Neghabi and Mahmoodnia (2015). As a significant shareholding is concentrated in the hands of block-holders, minority shareholders may have relatively low power to influence firm-controlling decisions. Moreover, it is probable that certain investors are afraid that large owners can carry out activities for their own interests in the expense of minority shareholders. Large owners may be not really ready for transacting stocks in order to maintain their control in the company. Therefore, those companies with high ownership concentration may be valued lower by the investors.

In terms of effects of the second largest shareholder, there is no statistical evidence that the presence of the second largest shareholders owning above 5 percent (DUMSEC) of Vietnamese companies have significant influence on companies' market performance. Although the result shows a positive influence of the second largest shareholder on firm performance, this result is statistically insignificant with p-value of 0.1880 .

Other factors including the second largest shareholding, firm size, leverage, asset turnover rate and sales growth rate show no significant effect on firm performance.

The empirical results of Model 3B are summarised in the Table 11:

Table 11. Empirical results of Model 3B

$R O A_{t i}=\alpha+\beta_{1}{ }^{*}$ FIRST $_{t i}+\beta_{2}{ }^{*} D U M S E C_{t i}+\beta_{3}{ }^{*} C O N T R O L_{t i}+\mu_{t i}$

\begin{tabular}{cccc}
\hline Dependent variable & & ROA & \\
\hline Independent variables & Coefficient & P-value & Relationship \\
\hline FIRST & 0.029225 & 0.7337 & \\
DUMSEC & -0.002244 & 0.8143 & \\
SIZE & -0.055597 & 0.0648 & \\
LEV & 0.005066 & 0.4510 & \\
\hline
\end{tabular}




\begin{tabular}{cccc}
\hline ASTURN & 0.059481 & 0.0010 & Significant \\
SALESGR & -0.002759 & 0.6546 & \\
R-squared & & 0.913356 & \\
Prob (F-statistic) & & 0.000000 & \\
\hline
\end{tabular}

Overall, the model is of significance because p-value is much lower than 5 percent. Moreover with high R-squared, independent variables in the model can explain 91.335 percent of ROA's fluctuation.

However, no significant evidence is found to show the relationship between ownership structure and ROA. All determinants of ROA except asset turnover rate indicate no clear connection with firm performance. These unexpected findings may be due to wide variation in financial data of sample companies.

\section{Conclusions}

Overall, the paper yields three significant conclusions: (i) firms with the presence of ownership concentration tend to increase their dividend payout; (ii) dividends are found to increase both market based and accounting based indicators of firm performance, as measured by P/E and ROA ratios; and (iii) ownership concentration decreases firm performance as measured by $\mathrm{P} / \mathrm{E}$ ratio. These conclusions are summarised in the figure 2 :

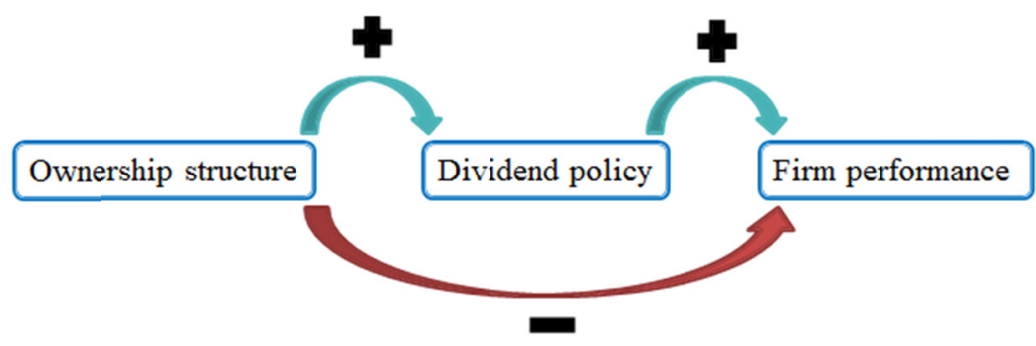

Figure 2. Conclusions of the paper

There are opposite results of the two approaches: the direct approach suggests a positive relationship between ownership structure and firm performance; however, the indirect approach shows that ownership structure can have positive effects on firm performance by increasing dividends. These unexpected results may be due to the small data sample of the paper, which suggests a direction for further research with larger data, and also the inefficient market with great data variation of Vietnam. However, these results are consistent with Juhandi, Sudarma, Aisjah and Rofiaty (2013) who also utilize both direct and indirect approaches. It is found out that institutional ownership worsens company's value; however, institutional ownership tends to increase dividends and dividends improve company's value.

Moreover, empirical analysis also indicates that EPS and MTBV have negative impacts on the magnitude of dividend payment. The final result is that asset turnover rate can help improve firm performance as measured by ROA.

\section{References}

Al-Gharaibeh, M., Zurigat, Z., \& Al-Harahsheh, K. (2013). The Effect of Ownership Structure on Dividends Policy in Jordanian Companies. Interdisciplinary Journal of Contemporary Research in Business.

Al-Nawaiseh, M. (2013). Dividend Policy and Ownership Structure: An Applied Study on Industrial Companies in Amman Stock Exchange. Journal of Management Research.

Amidu, M., \& Abor, J. (2006). Determinants of dividend payout ratios in Ghana. The Journal of Risk Finance.

Arshad, Z., Akram, Y., Amjad, M., \& Usman, M. (2013). Ownership structure and dividend policy. Interdisciplinary Journal of Contemporary Research in Business.

Bich, V., \& Yen, D. (2014). Mối quan hệ giũa chính sách cổ tức và cấu trúc sở hũu hình tháp của nhũng công ty niêm yết ở Việt Nam. University of Economics Ho Chi Minh City.

Juhandi, N., Sudarma, M., Aisjah, S., \& Rofiaty. (2013). The Effects of Internal factors and Stock Ownership Structure on Dividend Policy on Company's performance. International Journal of Business and 


\section{Management Invention.}

Khoshkhoo, O. I., Heydari, S. E., Rezaloie, A., Jalali, A. G., \& Poorghorban, A. (2013). Studying Relationship between Ownership Concentration and Corporate Performance in Companies Accepted In Tehran Stock Exchange. TextRoad Publication.

Kumar, J. (2003a). Ownership Structure and Dividend Payout Policy in India. Indira Gandhi Institute of Development Research.

Kumar, J. (2003b). Does Ownership Structure Influence Firm performance? Evidence from India. Indira Gandhi Institute of Development Research.

Neghabi, V., \& Mahmoodnia, D. (2015). Impact Of Ownership Structure (Concentration) On Firm Accounting Based And Market Based Performance: Evidence From Iran. A Journal of Economics and Management.

Ramli, N. M. (2010). Ownership Structure and Dividend Policy: Evidence from Malaysian Companies. International Review of Business Research Papers.

Ruan, W., Tian, G., \& Ma, S. (2011). Managerial Ownership, Capital Structure and Firm Value: Evidence from China's Civilian-run Firms. Australasian Accounting, Business and Finance Journal.

Thafani, F., \& Abdullah, M. (2014). Impact of Dividend Payout on Corporate Profitability: Evident from Colombo Stock Exchange. Advances in Economics and Business Management.

Thomsen, S. (2004). Blockholder Ownership, Dividends and Firm Value In Continental Europe. Department of International Economics and Management, Copenhagen Business School.

Tran, T. N. A. (2011). Chính sách cổ tức của các công ty niêm yết trên sàn HOSE tù̀ năm 2006 đến năm 2010. University of Economics Ho Chi Minh City.

Wahla, K., Shah, S. J. A., \& Hussain, Z. (2012). Impact of Ownership Structure on Firm Performance Evidence from Non-Financial Listed Companies at Karachi Stock Exchange. Euro Journals Publishing.

\section{Copyrights}

Copyright for this article is retained by the author(s), with first publication rights granted to the journal.

This is an open-access article distributed under the terms and conditions of the Creative Commons Attribution license (http://creativecommons.org/licenses/by/3.0/) 